(RESEARCH ARTICLE)

\title{
Anticonvulsant effect of Asparagus africanus Lam. root decoction on pilocarpine- induced temporal lobe epilepsy in white mice (Mus musculus Swiss)
}

\author{
Tchinmi Elisabeth 1, ${ }^{*}$, Ngah Esther 2, Njapdounke Kameni Jacqueline Stéphanie 1, Nkantchoua Nkamguie \\ Claudine Gisèle ${ }^{1}$, Jeweldai Vedekoi ${ }^{1}$ and Ngo Bum Elisabeth ${ }^{1}$ \\ ${ }^{1}$ Department of Biological Sciences, Faculty of Science, University of Ngaoundere, P.O. Box 454, Ngaoundere, Cameroon \\ 2 Department of Food Sciences and Nutrition, National School of Agro-Industrial Sciences, University of Ngaoundere, P.O. \\ Box 454 Ngaoundere, Cameroon.
}

Publication history: Received on 18 November 2020; revised on 26 November 2020; accepted on 28 November 2020

Article DOI: https://doi.org/10.30574/wjarr.2020.8.2.0431

\begin{abstract}
Asparagus africanus Lam. (Asparagaceae) is a widely used plant in traditional medicine as an anti-inflammatory, antioxidant, for the treatment of nervous disorders and epilepsy. The objective of this work was to study the anticonvulsant effects of $A$. africanus root decoction in white mice (Mus musculus Swiss) induced by pilocarpine. The experimental induction of "status epilepticus" and the evaluation of the anticonvulsant effects of $A$. africanus root decoction on pilocarpine-induced clonic and tonic convulsions were carried out. Seizure severity, latency, duration and number of clonics and tonics convulsions were evaluated. Concentrations of GABA, GABA-T, TNF- $\alpha$ and stress markers in the brains of mice were also estimated. A. africanus decreased the duration and number of clonic and tonic convulsions which increased the latency time of onset of clonic and tonic convulsions significantly and in a dosedependent manner. GABA increased significantly in the brains of animals treated with $A$. africanus and a significant decrease of GABA-T and TNF- $\alpha$. A. africanus also showed antioxidant effects. These results show that $A$. africanus has anticonvulsant effects. A. africanus would thus contain beneficial antiradical constituents in the treatment of epilepsy. These constituents would thus oppose free radicals. These results would justify the use of this plant in traditional medicine in the treatment of epilepsy.
\end{abstract}

Keywords: Asparagus africanus; Pilocarpine; Antioxidants; Anticonvulsants; Mouse.

\section{Introduction}

Epilepsy is a chronic disorder of the brain that results from excessive electrical discharges from neurons and is characterized by recurrent seizures manifested by brief episodes of involuntary shaking of part or all of the body [1]. Epilepsy is the most common neurological disorder after migraine, affecting all age groups [2]. It is the second leading cause of hospitalization in neurology after stroke [3]. Seizures in epilepsy can vary in intensity, ranging from brief loss of attention to severe and prolonged convulsions [4]. Epilepsy appears to the public as a shameful, dishonourable and supernatural disease [5]. It accounts for $0.6 \%$ of the global burden of disease and also has significant economic consequences [4]. Worldwide, about 70 million of people suffer from epilepsy, 80\% are found in developing countries [6]. Epilepsy is diagnosed in 2.4 million people each year worldwide, the vast majority of whom are in low- and middleincome countries [4].

The causes of epilepsy can be: brain damage due to prenatal or perinatal trauma, congenital anomalies or genetic disorders associated with brain malformations, severe head trauma, stroke, infection affecting the brain and brain tumour etc [4].

\footnotetext{
${ }^{*}$ Corresponding author: Tchinmi Elisabeth

Department of Biological Sciences, Faculty of Science, University of Ngaoundere, P.O. Box 454, Ngaoundere, Cameroon .
} 
Different treatments have been developed to treat the symptoms [3]. On the other hand, despite the large number of molecules, the number of drug-resistant epilepsies does not seem to be decreasing [7]. A non-negligible percentage of patients (about 30\%) continue to have seizures despite drug treatment. Temporal lobe epilepsies are among the most common forms of drug-resistant partial epilepsy [3]. They are drug resistant and surgery is one of the main therapeutic solutions [8]. The latter increases the risk of dead [3]. In addition, the lack of qualified personnel, the lack of health infrastructures and the high cost of surgery, shows that many patients do not have access to this practice [5].

Herbal pharmacotherapy for neurological diseases has been advancing due to fewer undesirable side effects and better tolerability [9]. Plants have extraordinary therapeutic virtues and it is estimated that nearly $75 \%$ of the African population has always used plants for self-care [10]. A. africanus also called "labbel fowru" (hyena spear) by the diamare fulbe in Cameroon, is used as a tuber by Musey and as an ingredient in porridge by kapsiki and fulbe in times of famine [11]. Aqueous and ethanolic extracts of the root of $A$. africanus were found to be less toxic and rich in phenolic compounds, a potential source of natural antioxidants that could be of great therapeutic importance in oxidative stress related to degenerative diseases [12]. A. africanus is widely used in traditional medicine as an anti-inflammatory [13], for the treatment of nervous disorders [14] and epilepsy. The objective of this work was therefore to evaluate the anticonvulsant effects of $A$. africanus root decoction on pilocarpine-induced temporal lobe epilepsy.

\section{Materials}

\subsection{Plant material}

The roots of $A$. africanus were collected in the town of Bini-Dang, in the Adamawa region (Cameroon). A sample of the plant has been deposited at the headquarters of the national herbarium in Yaoundé (Cameroon) under number 40168/HHC/Cam. The harvested roots of $A$. africanus were washed, dried at room temperature and then grounded. 500 $\mathrm{mL}$ of distilled water was added to $50 \mathrm{~g}$ of this powder and then brought to boil for 20 minutes on a hot plate set at 100 ${ }^{\circ} \mathrm{C}$. After cooling, the solution was filtered using Wattman number 1 filter paper, then evaporated in an oven $\left(70{ }^{\circ} \mathrm{C}\right)$ for $24 \mathrm{~h} .325 \mathrm{~mL}$ of distilled water was added to the dry extract obtained constituting the mother solution, the dose of which is $254 \mathrm{mg} / \mathrm{kg}$. Dilution with distilled water was made to $1 / 2$ and $1 / 4$ to obtain the 127 and $63.5 \mathrm{mg} / \mathrm{kg} \mathrm{doses}$ respectively.

\subsection{Animal material}

White mice (Mus musculus Swiss) of both sexes, weighing 20 to $29 \mathrm{~g}$ were used for the various tests. These mice were obtained at the National Veterinary Laboratory (LANAVET) of Garoua (North Cameroon) and further raised in a controlled environment (12 hours of darkness), with access to unlimited food and water. All experiments were performed in accordance with the Guide to the Care and Use of Laboratory Animals published by "National Institutes of Health of the United States" (NIH Publication No. 85-23, revised in 1996). In addition, the studying protocol for the handling of animals and the procedure for the experiment were approved by the National Ethics Committee of Cameroon (Ref. No. FW-IRB00001954).

\subsection{Drugs}

Pilocarpine, methylscopolamine, Sodium valproate and all other chemicals and reagents used in the evaluation of the amount gamma-aminobutyric acid (GABA), gamma-aminobutyric acid transaminase (GABA-T) and stress marquers in the brain are from Sigma Chemical, USA. Kit type "Quantikine" (France) was used for the determination of TNF- $\alpha$.

\section{Methods}

\subsection{Experimental induction of "epilepticus status"}

Mice homogeneously divided into six batches of five mice were treated with distilled water (10 mL/kg; p.o.) for the negative control batch, with different doses of $A$. africanus root decoction (63.5; 127 and $254 \mathrm{mg} / \mathrm{kg}$; p.o.) for the test batches and with sodium valproate (300 mg/kg; i.p.) for the positive control batch. A neutral group of mice was treated with distilled water and did not receive pilocarpine or methylscopolamine. Thirty minutes later, the mice were then each treated by intraperitoneal injection of $1 \mathrm{mg} / \mathrm{kg}$ of methylscopolamine to reduce the peripheral effects of pilocarpine [15]. Clonic and tonic convulsions ("status epilepticus") were induced 30 minutes after administration of methylscopolamine to mice by intraperitoneal injection of pilocarpine at a dose of $360 \mathrm{mg} / \mathrm{kg}$ [16]. Injection of pilocarpine causes rodents to experience severe myoclonic tremors followed by multiple tonic and clonic convulsions and motor convulsions $[16,17]$. The severity of convulsions was assessed in animals immediately after induction of 
"epilepticus status" according to the Root Scale from 0 to 5 (level 0: no response; level 1: hyperactivity and vibrational clonus; level 2: nodding, head clonus and myoclonic shaking; level 3: unilateral forelimb clonus; level 4: rearing and bilateral forelimb clonus; level 5: tonic and clonic convulsions with loss of motor control reflex) for a duration of 6 hours $[16,17,18]$. Mice having reached level 5 severity were selected for the following experiments.

\subsection{Anticonvulsant effects of Asparagus africanus root decoction on mice subjected to pilocarpine-induced "epilepticus status"}

Anticonvulsant effects were evaluated in mice previously subjected to "epilepticus status" with spontaneous convulsions characteristic of temporal lobe epilepsy. 23 hours after injection of pilocarpine to the mice, the mice were again given distilled water $(10 \mathrm{~mL} / \mathrm{kg})$ for the negative control lot, the different doses of $A$. africanus root decoction $(63.5 ; 127$ and $254 \mathrm{mg} / \mathrm{kg})$ for the test lots and sodium valproate $(300 \mathrm{mg} / \mathrm{kg}$ ) for the positive control lot. One hour after the administration of the different treatments, several behavioral parameters were evaluated in each mouse for a period of 60 minutes. The parameters observed were the latency time of appearance of the first tonic and clonic convulsion, the duration and number of tonic and clonic convulsions [19]. After evaluation of these parameters, the mice received the various treatments mentioned above for seven days and were then sacrificed.

\subsection{Gamma aminobutyric acid amounts}

The amount of GABA in the hippocampus of mice was evaluated by the colorimetric technique of mouse brain homogenates described by Lowe [20]. The working reagent consisted of a mixture of $0.2 \mathrm{~mL}$ of $0.14 \mathrm{M}$ ninhydrin solution prepared in a bicarbonate buffer solution ( $0.5 \mathrm{M}$; pH 9.9), and $0.1 \mathrm{~mL}$ of glacial trichloroacetic acid (TCA) $10 \%$. A 100 $\mu \mathrm{L}$ homogenate sample was taken and introduced into the working reagent, the mixture was incubated at $60{ }^{\circ} \mathrm{C}$ in a water bath for 30 minutes. After cooling, the mixture was added into $5 \mathrm{~mL}$ of copper tartrate solution prepared from $0.16 \%$ disodium carbonate, $0.03 \%$ copper sulphate and $0.0329 \%$ tartaric acid. The whole mixture was kept at a temperature of $25^{\circ} \mathrm{C}$ for 10 minutes. The fluorescence resulting from the reaction between ninhydrin and GABA in the basic medium was measured using a spectrofluorimeter and was proportional to the concentration of GABA in the homogenates. A standard GABA solution was prepared parallelly from different GABA masses (50, 100, 150, 200, 250, 300,350 and $400 \mu \mathrm{g}$ ) which were each mixed with $1.5 \mathrm{mg}$ of glutamate dissolved in $0.1 \mathrm{~mL}$ of $10 \%$ TCA. The concentration of GABA in the samples was determined by referring to the GABA calibration curve [21]. The content of GABA in the brain was expressed in $\mu \mathrm{g} / \mathrm{g}$ of brain tissue.

\subsection{Determination of gamma aminobutyric acid transaminase}

The activity of GABA-T was evaluated by the colorimetric assay method of Nayak and Chatterjee, [22]. $15 \mu \mathrm{mol}$ of $\alpha$ oxoglutarate, $15 \mu \mathrm{mol}$ of GABA, $10 \mu \mathrm{g}$ of pyridoxal phosphate, $0.1 \mathrm{~mL}$ of homogenate brain supernatant and $0.1 \mathrm{~mL}$ of $5 \%$ methanol were introduced in the tubes. The final volume of the mixture was made up to $3 \mathrm{~mL}$ with Tris-HCl buffer. The tubes were incubated at $37^{\circ} \mathrm{C}$ for 30 minutes. The reaction was completed after adding $0.5 \mathrm{~mL}$ of $20 \%$ glacial TCA. Just before recording, the absorbance of each sample was recorded at $610 \mathrm{~nm}$ after 30 and 90 s against a blank just after adding $1 \mathrm{~mL}$ iron chloride $\left(12 \% \mathrm{FeCl}_{3}\right)$. The color of the succinic semialdehyde acid and 3-methyl-2-benzothia-zolone2-hydrazone complex formed in the presence of $12 \% \mathrm{FeCl}_{3}$ was proportional to the concentration of GABA-T in the homogenates. The activity of GABA-T was estimated in $\mathrm{pg} / \mathrm{min} / \mathrm{g}$ of tissue according to the Beer-Lambert law.

\subsection{Evaluation of the antitumor necrosis factor-alpha (TNF- $\alpha$ )}

The determination of TNF- $\alpha$ was performed by the enzyme-linked to immunosorbent assay (ELISA) method using "Quantikine" type kits (France). Primary antibodies specific for TNF- $\alpha$ were previously fixed at the bottom of the wells of a microplate. For this purpose, the primary antibody solution was introduced into the wells of a microplate and then the microplate was incubated for $24 \mathrm{~h}$ at $4^{\circ} \mathrm{C}$ in a water bath. The next day, the plate was washed 5 times with the wash buffer as provided by the kit, then $50 \mu \mathrm{L}$ of the RD1-42 dilution solution was added to each well. Then, $50 \mu \mathrm{L}$ of the specific protein standard was added to each well for the positive control wells, $50 \mu \mathrm{L}$ of Tris buffer for the negative control wells, and $50 \mu \mathrm{L}$ of homogenate for the test wells. The microplates were then incubated for 2 hours at $37^{\circ} \mathrm{C}$, then each well was washed 5 times with the wash buffer. Subsequently, $100 \mu \mathrm{L}$ of biotin-conjugated specific capture antibody was added to each well. A second incubation of the microplate was performed for 2 hours at $37^{\circ} \mathrm{C}$ followed by a series of 5 washes with Wash Buffer. Next, $100 \mu \mathrm{L}$ of substrate, consisting of streptadivine coupled to peroxidase, was added to each well and the plate was incubated for 30 minutes at the temperature room and protected from light.

Finally, the enzyme reaction was stopped by adding $100 \mu \mathrm{L}$ of stop solution $\left(\mathrm{H}_{2} \mathrm{SO}_{4}\right)$ and then the absorbance for each well was read at $450 \mathrm{~nm}$ with a microplate ELISA reader. The concentrations of each cytokine were expressed in $\mu \mathrm{g} / \mathrm{mL}$, calculated by referring to the TNF calibration curve $\alpha$, performed with the values provided by the kit. 


\subsection{Determination of Superoxide Dismutase (SOD)}

The method used for this assay was that of Beauchamp and Fridovich [23]. An aliquot of $0.2 \mathrm{~mL}$ of sample was introduced into $2.5 \mathrm{~mL}$ of carbonate buffer $(0.1 \mathrm{M}, \mathrm{pH} 10.2)$. The reaction started with the addition of $0.3 \mathrm{~mL}$ of freshly prepared epinephrine to the mixture. After homogenization, the final mixture was read at $480 \mathrm{~nm}$ every 30 seconds up to 150 seconds to follow the increase in optic density. The reference vial contains $2.5 \mathrm{~mL}$ buffer, $0.3 \mathrm{~mL}$ adrenaline substrate and $0.2 \mathrm{~mL}$ distilled water. An absorbance unit of SOD activity will be defined as the amount of SOD required to cause $50 \%$ inhibition of the oxidation of adrenaline to adrenochrome for $1 \mathrm{~min}$. The activity will be expressed in units per milligram of protein. The enzyme activity of SOD will be expressed as follows: Inhibition Total x 100.

\subsection{Determination of malondialdehyde (MDA)}

The degree of lipid peroxidation was achieved by a protocol previously described by Ohkawa et al., [24]. A volume of $100 \mu \mathrm{L}$ of sample plus $500 \mu \mathrm{L}$ of orthophosphoric acid (1\%) sample and $500 \mu \mathrm{L}$ of thiobarbituric acid/glacial acetic acid (ATB 1\% / AAcl 1\%) were combined to form a mixture which was placed in a boiling water bath for $15 \mathrm{~min}$ at $100^{\circ} \mathrm{C}$. The tubes were then cooled in an ice bath. The absorbance of the supernatants was read at $530 \mathrm{~nm}$ against the white. The concentration of MDA is expressed in nanomoles per milligram of protein (nmol/mg prot) according to the following formula:

$D O=\Sigma \cdot L . C ; C=D O /(\Sigma \cdot L)$

\subsection{Catalase activity (CAT)}

CAT activity was determined in tissues according to the method described by Nassima et al., [25]. A substrate solution consisting of $1 \mathrm{~mL}$ of phosphate buffer $(0.1 \mathrm{M}, \mathrm{PH} 7.4), 950 \mu \mathrm{L}$ of hydrogen peroxide $\left(\mathrm{H}_{2} \mathrm{O}_{2}\right)$ solution $(0.019)$ and $250 \mu \mathrm{L}$ of the enzyme source was formed. The measurement of CAT activity was followed by recording the absorbance at 570 $\mathrm{nm}$ of the reaction mixture every minute for two minutes. The enzymatic activity of CAT was deduced by the BeerLambert law: CAT activity $=$ C. L.C

\subsection{Determination of reduced glutathione (RG)}

The determination of RG was carried out according to the protocol described by Ellman [26]. To perform this assay, 1.5 $\mathrm{mL}$ of Ellman's reagent was introduced into test tubes previously containing $100 \mu \mathrm{L}$ of homogenate and $100 \mu \mathrm{L}$ of phosphate-saline buffer $(0.1 \mathrm{M}, \mathrm{pH} 7.4)$. The tubes were shaken and left to stand for incubation for one hour at room temperature, then the absorbance was read on the spectrophotometer at $412 \mathrm{~nm}$ against the blank. The amount of RG was determined using the following formula:

$$
[\text { Reduced glutathione }](\text { mol } / g \text { tissue })=\left(\frac{D O \times V t}{\varepsilon \times L \times V i \times m}\right) \times 2
$$

\subsection{Statistical analysis}

The statistical analysis was carried out using GraphPad Prism software version 8.0.1. The results were expressed as mean \pm standard error (S.E.M). The different values were compared using analysis of variance (ANOVA) and Tukey's multiple comparison.

\section{Results}

\subsection{Effects of Asparagus africanus root decoction on the severity of tonic and clonic convulsions induced by pilocarpine}

Pilocarpine $(360 \mathrm{mg} / \mathrm{kg})$ injected intraperitoneally one hour after administration of the negative control to mice with distilled water caused tonic and clonic convulsions which are characteristic of the epileptic condition also called "status epilepticus". The different doses of A. africanus root decoction $(63.5,127$ and $254 \mathrm{mg} / \mathrm{kg}$ ) did not protect the mice against pilocarpine-induced status epilepticus. Sodium valproate $(300 \mathrm{mg} / \mathrm{kg})$ injected intraperitoneally, which is an 
antiepileptic reference, also did not show a significant effect against "status epilepticus" in mice. In this experiment, all mice reached the highest severity of status epilepticus, i.e. level 5 on the Root Scale.

\subsection{Effects of Asparagus africanus root decoction on the latency time, duration and number of tonic and clonic convulsions induced by pilocarpine}

All doses A. africanus roots decoction increased the latency time of tonic and clonic convulsions $[(\mathrm{F}(5,24)=477.8 ; \mathrm{P}$ $<0.001$ ); $\left.\mathrm{R}^{2}=99.01 \%\right]$ (Figure 1), decreased the duration of tonic and clonic convulsions $[(\mathrm{F}(5,24)=218.90 ; \mathrm{P}<0.001)$; $\left.\mathrm{R}^{2}=97.85 \%\right]$ (figure 2$)$ and reduced the number of tonic and clonic convulsions $\left[(\mathrm{F}(5,24)=85.24 ; \mathrm{P}<0.001) ; \mathrm{R}^{2}=\right.$ 94.67\%] (figure 3); significantly comparable to sodium valproate which is a antiepileptic reference as compared to the negative control lot.

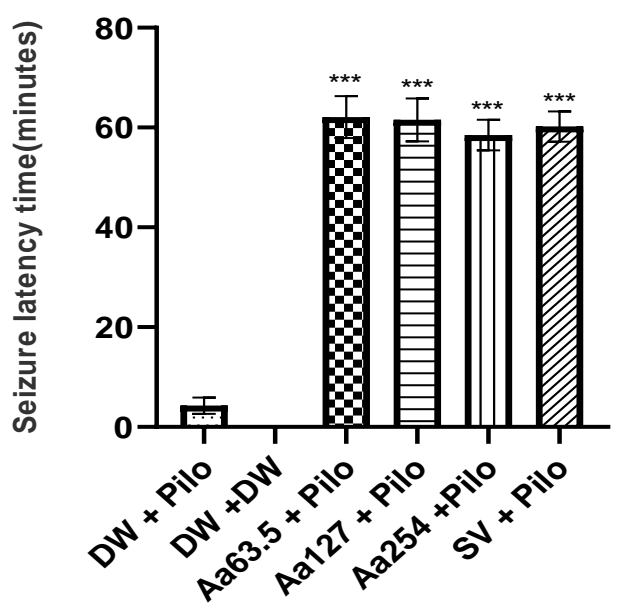

Treatments administered to $\mathrm{mice}(\mathrm{mg} / \mathrm{kg})$

Figure 1: Effects of Asparagus africanus root decoction on the latency time of pilocarpine-induced tonic and clonic convulsions.

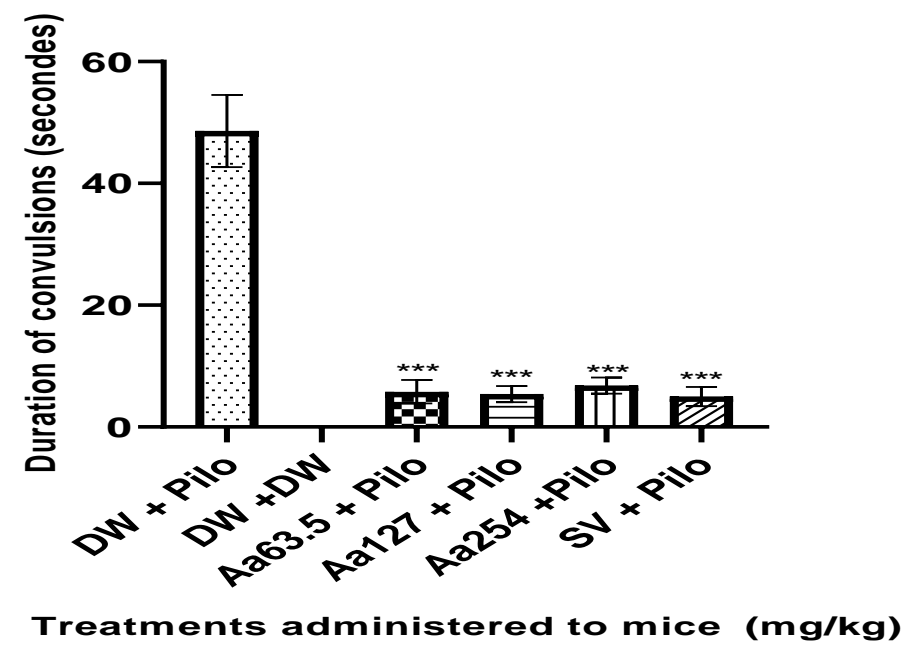

Figure 2: Effects of Asparagus africanus root decoction on the duration of pilocarpine-induced tonic and clonic convulsions. 


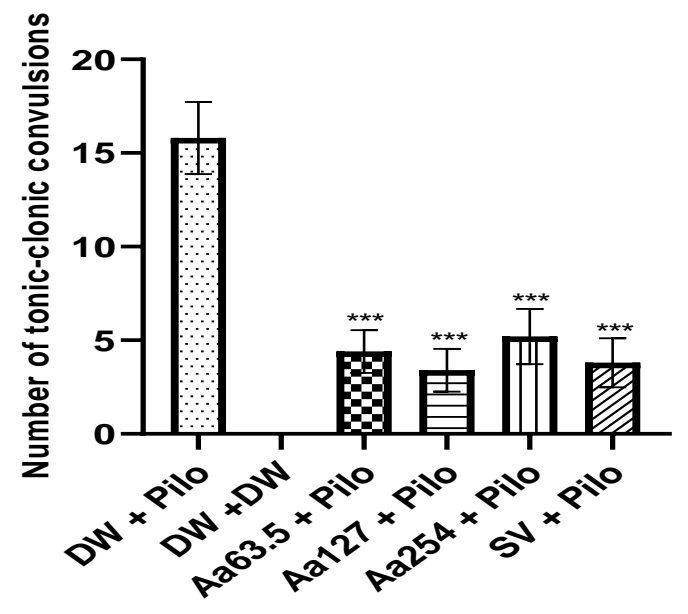

Treatments administered to mice $(\mathrm{mg} / \mathrm{kg})$

Figure 3: Effects of Asparagus africanus root decoction on the number of tonic and clonic convulsions induced by pilocarpine.

Each bar represents the mean $\pm \mathrm{ESM}, \mathrm{n}=5 .{ }^{* * *} \mathrm{p} \leq 0.001$, significant difference from negative control. DW + Pilo: negative control consisting of pilocarpinized mice treated with distilled water, DW + DW: normal control consisting of mice treated with distilled water, SV: positive control consisting of mice treated with sodium valproate $(300 \mathrm{mg} / \mathrm{kg})$, Aa: Asparagus africanus.

\subsection{Effect of Asparagus africanus root decoction on gamma-aminobutyric acid, gamma-aminobutyric acid transaminase and antitumor necrosis factor-alpha in the hyppocampus of mice epilepticised by pilocarpine}

Table 1 shows a significant depedent doses increase in GABA concentration $\left[(F(5,24)=134.7 ; P<0.001) ; R^{2}=99.12 \%\right]$, decrease in GABA-T concentration $\left[(\mathrm{F}(5,24)=29.54 ; \mathrm{P}<0.001) ; \mathrm{R}^{2}=96.10 \%\right]$ and decrease in TNF- $\alpha$ concentration $\left[(\mathrm{F}(5,24)=87.45 ; \mathrm{P}<0.001) ; \mathrm{R}^{2}=98.65 \%\right]$ comparable to normal mice and mice treated with sodium valproate (positive control) compared to the negative control lot.

Table 1: Effect of Asparagus africanus root decoction on gamma-aminobutyric acid, gamma-aminobutyric acid transaminase and antitumor necrosis factor-alpha.

\begin{tabular}{|l|l|l|l|l|}
\hline Treatments & Doses $(\mathbf{m g} / \mathbf{k g})$ & GABA $(\boldsymbol{\mu g} / \mathbf{g})$ & GABA-T $(\boldsymbol{\mu g} / \mathbf{g})$ & TNF- $\boldsymbol{\alpha}$ \\
\hline DW + DW & -+- & $374.54 \pm 4.68^{* * *}$ & $33.77 \pm 4.38^{* * *}$ & $291.99 \pm 5.24^{* * *}$ \\
\hline DW + Pilo & -+360 & $293.98 \pm 5.07_{\mathrm{c}}$ & $77.56 \pm 6.45_{\mathrm{c}}$ & $371.39 \pm 6.90_{\mathrm{c}}$ \\
\hline Aa + Pilo & $63.5+360$ & $385.15 \pm 3.88^{* * *}$ & $30.98 \pm 0.11^{* * *}$ & $289.72 \pm 3.99^{* * *}$ \\
\hline Aa + Pilo & $127+360$ & $384.83 \pm 4.41^{* * *}$ & $41.27 \pm 2.75^{* *}$ & $334.69 \pm 4.59^{*} \mathrm{~b}$ \\
\hline Aa +Pilo & $254+360$ & $376.20 \pm 3.07^{* * *}$ & $48.97 \pm 6.46^{* *}$ & $356.32 \pm 5.16_{\mathrm{c}}$ \\
\hline SV +Pilo & $300+360$ & $369.99 \pm 4.08^{* * *}$ & $36.50 \pm 3.24^{* * *}$ & $319.04 \pm 3.75^{* *} \mathrm{a}$ \\
\hline
\end{tabular}

Each value represents the mean \pm ESM; $\mathrm{n}=5$. $^{*} \mathrm{p} \leq 0.05,{ }^{* *} \mathrm{p} \leq 0.01,{ }^{* *} \mathrm{p} \leq 0.001$ : significant difference from negative control; a $\mathrm{p} \leq 0.05$, ${ }^{\mathrm{b}} \mathrm{p} \leq 0.01, \mathrm{c} \mathrm{p}$ $\leq$ 0.001: significant difference from normal control; DW + Pilo: negative control consisting of pilocarpinized mice treated with distilled water; DW + DW: normal control consisting of mice treated with distilled water; SV: positive control consisting of mice treated with sodium valproate (300 $\mathrm{mg} / \mathrm{kg}$ ); Aa: Asparagus africanus.

\subsection{Effects of Asparagus africanus root decoction on malondialdehyde, catalase, reduced glutathione and superoxide dismutase in the hyppocampus of mice epilepticised by pilocarpine}

Table 2 shows that administration of $A$. africanus root decoction resulted in a significant decrease in MDA $[(\mathrm{F}(5,24)=$ 34.45; $\left.\mathrm{P}<0.001) ; \mathrm{R}^{2}=93.49 \%\right]$ and a significant increase in CAT $\left[(\mathrm{F}(5,24)=126.60 ; \mathrm{P}<0.001) ; \mathrm{R}^{2}=98.14 \%\right], \mathrm{RG}[(\mathrm{F}(5$, $\left.24)=135 ; \mathrm{P}<0.001) ; \mathrm{R}^{2}=99.12 \%\right]$ and $\mathrm{SOD}\left[(\mathrm{F}(5,24)=55.15 ; \mathrm{P}<0.001) ; \mathrm{R}^{2}=97.87 \%\right]$ in epileptic mice comparable to mice treated with sodium valproate (positive control) compared to the negative control lot. 
Table 2: Effect of Asparagus africanus root decoction on malondialdehyde, catalase, superoxide dismutase and reduced glutathione in the hippocampus of pilocarpine-treated mice with epilepsy.

\begin{tabular}{|c|c|c|c|c|c|}
\hline Treatments & $\begin{array}{l}\text { Doses } \\
\text { (mg/kg) }\end{array}$ & $\begin{array}{l}\text { MDA } \\
\text { (nmol/mg) }\end{array}$ & $\begin{array}{l}\text { CAT } \\
(\mathrm{mM} / \mathrm{min} / \mathrm{mL})\end{array}$ & SOD $(\mathrm{U} / \mathrm{mL})$ & RG (mol/g) \\
\hline $\mathrm{DW}+\mathrm{DW}$ & -+ & $1.02 \pm 0.01^{* * *}$ & $404.76 \pm 1.39^{* * *}$ & $22.15 \pm 0.01^{* * *}$ & $315.44 \pm 1.04^{* * *}$ \\
\hline DW + Pilo & -+360 & $1.29 \pm 0.03 c$ & $352.64 \pm 5.55_{c}$ & $12.45 \pm 0.00_{c}$ & $254.41 \pm 4.16_{c}$ \\
\hline Aa + Pilo & $63.5+360$ & $1.03 \pm 0.02^{* * *}$ & $372.68 \pm 2.40^{* * *}$ & $17.95 \pm 0.00_{b} * * *$ & $295.22 \pm 2.60_{b} * * *$ \\
\hline Aa + Pilo & $127+360$ & $1.15 \pm 0.02 b^{* *}$ & $363.86 \pm 1.39{ }^{* *}$ & $16.65 \pm 0.01^{* *}$ & $281.62 \pm 3.12 c^{* * *}$ \\
\hline Aa + Pilo & $254+360$ & $1.21 \pm 0.06 \mathrm{c}$ & $357.45 \pm 3.67 c$ & $15.80 \pm 0.00_{c}^{*}$ & $276.47 \pm 2.08^{* *}$ \\
\hline SV + Pilo & $300+360$ & $1.02 \pm 0.00^{* * *}$ & $391.91 \pm 2.40_{b}{ }^{* * *}$ & $18.80 \pm 0.00_{\mathrm{a}}{ }^{* * *}$ & $303.31 \pm 1.56_{a}{ }^{* * *}$ \\
\hline
\end{tabular}

Each value represents the mean $\pm \mathrm{ESM} ; \mathrm{n}=5{ }^{*} \mathrm{p} \leq 0.05,{ }^{* *} \mathrm{p} \leq 0.01,{ }^{* * *} \mathrm{p} \leq 0.001$ : significant difference from negative control; ${ }^{\mathrm{a}} \mathrm{p} \leq 0.05$, ${ }^{\mathrm{b}} \mathrm{p} \leq 0.01,{ }^{\mathrm{c}} \mathrm{p}$ $\leq$ 0.01: significant difference from normal control; DW + Pilo: negative control consisting of pilocarpinized mice treated with distilled water; DW + DW: normal control consisting of mice treated with distilled water; SV: positive control consisting of mice treated with sodium valproate (300 $\mathrm{mg} / \mathrm{kg}$ ); Aa: Asparagus africanus.

\section{Discussion}

The administration of $A$. africanus root decoction protected the mice against pilocarpine-induced convulsion severity (360 mg/kg) by significantly increasing the latency time of tonic and clonic convulsions on the one hand, and by decreasing the duration and number of tonic and clonic convulsions on the other hand. Pilocarpine is a cholinergic agonist that binds to acetylcholine (M1) at muscarinic receptors. At the cerebral level, these receptors are expressed in the cortex, hippocampus, amygdala, basal ganglia and striatum [27]. Activation of M1 receptors leads to the genesis of epileptic seizures via secondary release of glutamate [28]. The delay in the onset of pilocarpine-induced convulsions suggests that decoction of $A$. africanus roots has anticonvulsant properties. It antagonizes pilocarpine-induced seizures, suggesting an interaction with GABAergic neurotransmission [29,30,31]. In the present study, pilocarpine induced tonic and clonic convulsions in mice from the negative control batch. Protection against pilocarpine-induced convulsions suggests that decoction of $A$. africanus would have anticonvulsant properties and could be used against partial epilepsy, specifically temporal lobe epilepsy [32]. Sodium valproate has anticonvulsant effects with a broad spectrum of activity. The protective effect of the decoction of $A$. africanus roots and sodium valproate on pilocarpineinduced convulsions is believed to result in the neural mechanism of inhibition of voltage-dependent sodium channels in favour of increasing GABA concentration at central nervous system synapses with facilitation of GABAergic neurotransmission, reduction of $\mathrm{N}$-methyl-D-aspartate and glutamate receptors, and with attenuation of nerve inflammation [33]. These observations suggest that decoction of $A$. africanus roots could have altered the epileptogenesis process by increasing GABAergic activity and reducing excitatory neurotransmission [34].

In the GABAergic neurotransmission studies of $A$. africanus root decoction in pilocarpine-induced temporal lobe epilepsy, the concentration of GABA and the activity of GABA-T were evaluated. GABA is the major inhibitory neurotransmitter in the brain and is widely implicated in epilepsy. GABA-ergic neurotransmission or activity is known to inhibit or attenuate seizures [35]. Decoction of $A$. africanus roots significantly and dose-dependently increased GABA concentration and decreased GABAtransaminase activity. Any substance that decreases GABAtransaminase activity by increasing GABA concentration would have antiepileptic effects [36]. GABA is thus involved in the mechanisms of action of anticonvulsants [37]. The cerebral increase of GABA would be due to the stimulation of the activity of GABAergic neurons by the decoction of the roots of $A$. africanus which would release more GABA. This is the case of sodium valproate, an antiepileptic that induces an increase in the amount of cerebral GABA by inhibiting GABA-T (GABA-Tdegrading enzyme) or by activating GABA synthesis with Glutamic acid decarboxylase [38, 39]. The increase in GABAergic neurotransmission would therefore be responsible for the anticonvulsant properties. Given that the decoction of $A$. africanus roots induced the same effects and often better than sodium valproate, a standard antiepileptic, the decoction of $A$. africanus would thus have anti-epileptic properties. 
According to the work of Auvin and Sankar, [40], there is a reciprocal relationship between epileptic seizures and cytokines. On the one hand, pro-inflammatory cytokines have been shown to have pro-convulsant properties. On the other hand, a state of epilepsy is responsible for the cerebral expression of inflammatory cytokines such as IL- $1 \beta$, IL-6 and TNF- $\alpha$. TNF- $\alpha$ is a ubiquitous inflammatory cytokine that acts via membrane receptors on the NF- $\kappa \mathrm{B}$ signalling pathway. To evaluate the anti-inflammatory effects of $A$. africanus root decoction, TNF- $\alpha$ was assayed in pilocarpineinduced mouse hypocammal. TNF- $\alpha$ is elevated in the brains of patients [41]. According to Mogi and collaborators [42], excess TNF- $\alpha$ is toxic to cells although at a low dose it has neurotrophic effects on hippocampal neurons and protects neurons in culture from glutamate, free radicals, and the toxicity of $\beta$-A [43]. Decoction of the roots of $A$. africanus decreased the concentration of TNF- $\alpha$ significantly and dependently the dose. These results are in concord with the work of Hassan and collaborators [13] who show that A. africanus has anti-inflammatory effects.

Determination of the antioxidant effects of $A$. africanus root decoction was done by evaluating the levels of MDA, RG, SOD and CAT in the hipocammus of pilocarpine-induced mice. The results obtained show that the $\operatorname{decoction}$ of $A$. africanus roots significantly and dose-dependently increased the concentration of RG, SOD and CAT. SOD eliminates the superoxide anion by a dismutation reaction, transforming it into hydrogen peroxide and oxygen. Glutathione peroxidase reduces peroxides by removing lipid peroxides resulting from the action of oxidative stress on polyunsaturated fatty acids [44] and CAT removes $\mathrm{H}_{2} \mathrm{O}_{2}$ and its toxic radicals resulting from the antioxidant action of SOD [34]. These results suggest that the decoction of $A$. africanus roots would have antioxidant effects. Most of these antioxidants produce dioxides and peroxyl radicals, the latte, after being transform into a cyclic peroxide, release various toxic aldehydes including MDA [45]. The decoction of the roots of $A$. africanus significantly decreased the concentration of MDA. Furthermore, these effects are comparable to those of sodium valproate, a drug known to prevent oxidative stress [46, 47]. These results corroborate with the work of Onyeka, [12] who shows that A. africanus has good antioxidant potential. The decoction of $A$. africanus roots would thus have beneficial antiradical constituents in the treatment of epilepsy, since these constituents oppose free radicals when the body's antiradical defense system is deficient.

\section{Conclusion}

The objective of this work was to demonstrate the anticonvulsant effects of the decoction of the roots of $A$. africanus. The decoction of the roots of $A$. africanus has anticonvulsant properties that were visible in the antagonism of pilocarpine-induced epileptic seizures. It also showed anti-inflammatory effects by decreasing the concentration of TNF $\alpha$ which at high concentrations is toxic to neurons. The decoction of the roots of $A$. africanus has also shown antioxidant effects. A. africanus would thus contain beneficial antiradical constituents in the treatment of epilepsy. The antiepileptic activity would thus be due to their actions on the radicals that destabilize the neuronal membranes. These results would justify the use of this plant in traditional medicine as an anticonvulsant, antioxidant and antiinflammatory.

\section{Compliance with ethical standards}

\section{Acknowledgments}

The authors are very thankful to the Laboratory of Medicinal plants, Health and Galenic Fomulation, Faculty of Sciences, University of Ngaoundéré, P.O. Box 454 Ngoundéré, Cameroon, for supporting us by providing apparatus and drugs.

\section{Disclosure of conflict of interest}

All authors declare that they have no conflict of interest.

\section{Statement of ethical approval}

The experiment was carried out at the Laboratory of Medicinal plants, Health and Galenic Fomulation, Faculty of Sciences, University of Ngaoundéré in accordance with approval by the National Ethics Committee of Cameroon (Ref. No. FW-IRB00001954).

\section{References}

[1] WHO. 2017. Memory Help N999, media center, epilepsy.

[2] Hédon C, Chiron C and Gallo DA. 2017. Epilepsy" health priority http://savoirs.rfi.fr/. 
[3] Caparos M. Automatic analysis of temporal lobe epilpesia seizures from surface EEGs. PhD thesis from the Institut National Polytechnique de Lorraine-France, 2006; 6-18.

[4] WHO. 2018. Main landmarks on epilepsy. Megiddo I, Colson A, Chrisholm D, Dua T, Nandi A and Laxminarayan R. 2106. Health and economic benefits of public financing of epilepsy treatment in India an agent-based simulation. Epilepsia official journal of the international league against epilepsy.

[5] Houeto SOE. Therapeutic itinerary for epileptics in the district of Zou in Benin. Thesis for the State Doctorate in Medicine, Faculty of Health Sciences, University of Abomey-calavi, Cotonou, (1236), 77.

[6] Jost J. Determinants of the therapeutic deficit in epilepsy: the role of the quality of antiepileptic drugs in subSaharan Africa: Doctoral thesis in Medicine (Public Health). University of Limoges, France, 2018; 29-55.

[7] Longo V. The ketogenic diet in the treatment of epilepsy in children. Doctorate thesis in pharmacy. Faculty of Pharmacy, University Henri Poincare-Nancy 1-France, 2009; 3-46.

[8] Epsztein J. Role of kainate receptors in synaptic transmission: a study in the rat hippocampus control and in an animal model of temporal lobe epilepsy. Neuroscience [q-bio.NC]. University of Provence - Aix-Marseille I, 2006. French. 2005; P 13-34.

[9] Zhang ZJ. Therapeutic effects of herbal extracts and constituents in animal models of psychiatric disorders. Life Sciences, 2004; 75, 1659-1699.

[10] Svoboda K and Svoboda T. Secretory structures of aromatic and medicinal plants. Ed: microscopix publication, 2000; 7-12.

[11] Seignobos C and Iyebi-Mongjeck O. Atlas of the Far North Province of Cameroon. Ministry of Scientific and Technical Research (Cameroon), 2000; 111-112.

[12] Onyeka DO. An evaluation of the antidiabetic properties Asparagus africanus Lam. Root extracts. Magister technologiae: Biomedical technology, Faculty of Health and Environmental Sciences. Department of Health Science. Central University of technology, Free State (South Africa), 2014; 5-22.

[13] Hassan HS, Ahmadu AA and Hassan AS. Analgesic and anti-inflammatory activities of Asparagus africanus root extract. African Journal of Traditional, Complementary and Alternative Medicine, 2008; 5 (1): 27-31.

[14] Grieve M. A modern herb. Hafner Press, New York, 1992; 574.

[15] Covolan L and Mello L. Evaluation of the progressive nature of cell damage in the pilocarpine model of epilepsy. Braz J Med Biol Res, 2006; 39:915-924.

[16] Cavalheiro EA, Leite JP, Bortolotto ZA, Turski WA, Ikonomidou C and Turski L. Long-term effects of pilocarpine in rats: structural brain damage triggers flashover and spontaneous recurrent seizures. Epilepsia, 1991; 32:778782.

[17] Lemos T and Cavalheiro EA. Suppression of pilocarpine-induced epileptic condition and late development of epilepsy in rats. Exp Brain Res, 1995; 102:423-428.

[18] Racine RJ. Modification of epileptic activity by electrical stimulation: II Motor crisis. Electroencephalogr Clin Neurophysiol, 1972; 32:281-294.

[19] Moto FCO, Arsa'a A, Ngoupaye GT, Taiwe GS, Njapdounke JSK, Kandeda AK, Nkantchoua GCN, Omam Omam JP, Pale S, Kouemou NE, Ayissi Mbomo ER, Pahaye DB, Ojong L, Mairara V and Ngo Bum E. Anxiolytic and antiepileptic properties of an aqueous extract of Cissus quadrangularis (Vitaceae) in pilocarpine mouse models of epilepsy. Pharmacol, 2018; 9:751.

[20] Lowe IP, Robins E and Eyermen GS, Fluorimetric measurement of glutamic decarboxylase and its distribution in the brain. Journal of neurochemistry, 1958; 3:8-16.

[21] Sutton I and Simmonds M. Effects of acute and chronic pentobarbitone on the system $\beta$ - aminobutyric acid in the brain of the rat. Biochem.Pharmacology, 1974; 23:1801-1808.

[22] Nayak P and Chatterjee AK. Effects of aluminium exposure on brain glutamate and GABA systems: an experimental study in rats. Food and Chemical Toxicology, 2001; 39 (12):1285-1289.

[23] Beauchamp C and Fridovich I. Superoxide dismutase: improved tests and a test applicable to acrylamide gels. Analytical biochemistry, 1971; 44:276-287. 
[24] Ohkawa H, Ohishi N and Yagi K. Determination of lipid peroxides in animal tissues by reaction with thiobarbituric acid. Analytical biochemistry, 1979; 95 (2):351-358.

[25] Nassima B, Mesba L, Chebab S, Tekouk M and Leghouchi E. Oxidative stress induced by co-exposure to lead and cadmium: two contaminants of the groundwater of Oued Nile (Jijel - Algeria). Journal of Water Science, $2010 ; 23$ (3):197-323.

[26] Ellman GL. Sulfhydryl tissue groups. Arch. Biochem. Biophys. 1959; 82:70-77.

[27] Kuhar M and Yamamura HI. Localization of muscarinic cholinergic receptors in the rat brain by radio-autography under an optical microscope. Brain Res. 1976; 110:229-243.

[28] Cruickshank JW, Brudzynski SM and McLachlan RS. Involvement of muscarinic M1 receptors in the initiation of cholinergic epileptic seizures in the rat brain. Brain Res. 1994; 643:125-129.

[29] Mustafa AMS and Ali AM. The substance contained in the beans (Viciafaba) is protective against experimentally induced convulsions in mice. Epilepsy Behavior, 2008; 12:25-29.

[30] Perez-Saad H and Buznego MT. Behavioural and antiepileptic effects of the acute administration of the extract of the plant Cestrium nocturmum Lin (Lady of the Night). Epilepsy and Behavior, 2008; 12 (3):366-372.

[31] Talla E, Ngatcha S, Njapdounke J, Nkantchoua G, Yaya GAJ, Ngo Bum E, Mbafor TJ and Njintang YN. An anticonvulsant and sedative analogue effect of Abyssinone V-4' methyl ether isolated from Erythrina droogmansiana (Leguminosae). J App Pharm Sci, 2015; 5 (10):001-005.

[32] Loscher WH and Potschka. Role of multiple drug carriers in antiepileptic drug resistance. J Pharmacol Exp Ther, 2002; 301:7-14.

[33] Chapman AG, Meldrum BS and Mendes E. Acute anticonvulsant activity of structural analogue of valproic acid and modification of GABA and aspartate in the brain content. Life Science 1983; 32:2023-2031.

[34] Kandeda AK, Taiwe GS, Moto FCO, Ngoupaye GT, Nkantchoua GCN, Njapdounke JSK, Omam JPO, Pale S, Kouemou $\mathrm{N}$ and Ngo Bum E. Antiepileptogenic and Neuroprotective Effects of Pergularia daemia on Pilocarpine Model of Epilepsy. Pharmacol. 2017; 8:440.

[35] Li-Ping G, Xian-Yu S, Guan-Rong T, Kyu-Yun C. and Zhe-shan Q. The Synthesis and Anticonvulsant Activity of 1Substituted - 7- Methoxy -1,2,4- Triazolo [4, 3-a] Quinoline. Turkish Journal of Chemistry, 2008; 32 (2):181-189.

[36] Taiwe GS, Moto FCO, Ayissi ERM, Ngoupaye GT, Njapdounke JSK, Nkantchoua GCN, Kouemou N, Omam JPO, Kandeda AK., Pale S, Pahaye D and Ngo Bum E. Effects of a freeze-dried aqueous extract of Feretia apodanthera Del. (Rubiaceae) on pentylenetetrazole-induced flashover, oxidative stress and cognitive impairment in mice. Epilepsy \& Behavior, 2015; 43:100-108.

[37] Evans AK and Lowry CA. Pharmacology of b-carboline FG 7142, an inverse agonist at the allosteric site of the benzodiazepines of the GABAA receptor: neurochemical, neurophysiological and behavioral effects. CNS drug reviews $2007 ; 13: 475-501$.

[38] McDonald RL and Olsen RW. GABAA receptor channels. Annual Review of Neurosciences, 1994; 17:569-602.

[39] Hashimoto Y, Araki H, Suemaru K and Gomita Y. Effects of drugs acting on the GABA-benzodiazepine receptor complex on flurothyl-induced seizures in Mongolian gerbils, European. Journal of Pharmacology, 2006; 536:241247.

[40] Auvin S and Sankar R. Inflammation, epilepsy and anti-inflammatory therapies. Pediatric Epilepsy: Diagnosis and Therapy New York: Demos Medical Publishing. 2008

[41] Tarkowski E, Blennow K, Wallin A and Tarkowski A. Intracerebral production of tumor necrosis factor-alpha, a local neuroprotective agent, in Alzheimer disease and vascular dementia. J Clin Immunol, 1999; 19 (4):223-230.

[42] Mogi M, Minoru H, Peter R, Hirotaro N, Keisuke F and Toshiharu N. Tumor Necrosis Factor- $\alpha$ (TNF- $\alpha$ ) increases in both the brain and cerebrospinal fluid of parkinsonian patients. Neuroscience Letters, 1994; 165:208-210.

[43] Barger SW, Hörster D, Furukawa K, Goodman Y, Krieglstein J and Mattson MP. Tumor necrosis factors alpha and beta protect neurons against the toxicity of beta-amyloid peptides: evidence for the involvement of a kappa B binding factor and attenuation of peroxide and $\mathrm{Ca}^{2+}$ accumulation. Proc Natl Acad Sci, 1995; 92 (20):9328-9332.

[44] Haleng JJ, Pincemail J0, Defraigne C, Charlier JP and Chapelle. Oxidative stress. Rev Med Liege, $2007 ; 62$ (10): 628-638. 
[45] Favierest A. Lesions of nucleic acids. Grenoble Nuclear Study Center, Martyrs street, 2003; 38054:115.

[46] Xavier SM, Barbosa CO, Barros DO, Silva RF, Oliveira AA and Freitas RM. Antioxidant effects of vitamin C in the hippocampus of adult Wistar rats after seizures and pilocarpine-induced epilepsy. Neuroscience Lett. 2007; 420:76-79.

[47] dos Santos PS, Costa JP, da Rocha TA, Saldanha GB, de Souza GF and Feng D. Alpha-tocopherol decreases oxidative stress in rat striatum after pilocarpine-induced seizures. Eur. J. Pharmacol. 2011; 668:65-71. 